\title{
Factors influencing the implementation of the auditor general's recommendations in South African municipalities
}

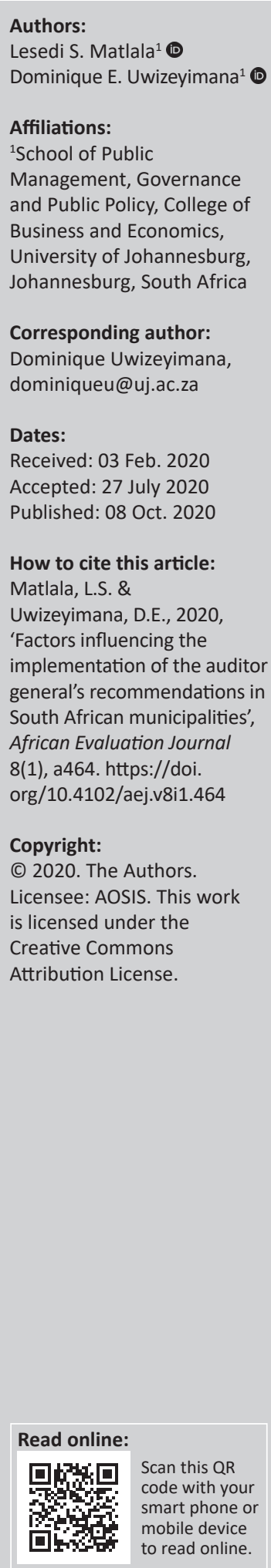

Background: The establishment of democratic local government in South Africa in 2000 decentralised the decision-making powers from the centre to the periphery. Municipalities are accountable for their own financial preparation and the planning of their budgetary processes. Notwithstanding the enormous investment in terms of resources, empirical studies and municipal audit reports revealed that most of the South African municipalities were not taking corrective action on the issues of irregularities raised in prior year audits; hence, some of the weaknesses and problems remained unresolved or were recurring yearly.

Objectives: To identify and discuss the factors that influence municipalities' failure to implement audit recommendations given by the Auditor General of South Africa (AGSA) efficiently and effectively.

Methods: The research methodology used in this study was mainly qualitative and relied heavily on robust literature study and the review of key official documents, such as reports on local government performance.

Results: The main findings of this study are that factors influencing implementation of audit recommendation include availability of resources and time, lack of audit action monitoring processes, absence of authority, staffing problems and sometimes the poor quality of audit recommendations.

Conclusion: To deal with these problems, the study recommends a number of practical strategies. These include regular progress monitoring, improving the quality of the AGSA's recommendations and the amendment of the Public Audit Act to empower the auditor general. Most importantly, the study recommends the establishment of a monitoring and evaluation (M\&E) unit to regularly track progress for proper implementation of audit recommendations in the South African municipalities.

Keywords: auditor general; audits; audit recommendations; implementation; local government.

\section{Introduction}

In local governments, as in any other public-sector organisation in South Africa, the role of the Auditor General of South Africa (AGSA) is to audit their financial and other statutory reports and outputs, and thus to increase public confidence in their management of the municipality (AGSA 2012/13a:19-196). The AGSA's authority to audit local government entities is derived from its competencies and abilities and its constitutionally defined mandate to serve the public within the prescribed legal frameworks by applying ethical principles and professional standards at all times (RSA 1996:5). Section 188(1) of Chapter 9 of the Constitution provides the basis upon which the Office of the Auditor General of South Africa (OAGSA) audits and reports on the accounts, financial statements and financial management of the public institutions (RSA 1996:9). Thus, the AGSA is one of the key role-players that support the constitutional democracy in South Africa by providing independent assurance on the use of tax and other monies by all levels of government (Matlala 2018).

According to Chaka (2013:1), '[l]ocal government is mainly responsible for the delivery of basic services to local communities' (see also Apollo 2008:15):

The White Paper accentuates that a developmental type of local government system must promote developmental objectives, with an emphasis on serving and creating a better life for all South African citizens. (White Paper 1998:26, cited in Chaka 2013:1) 
By implication, the above quote refers to effective service delivery (Chaka 2013:1). Thus, 'the quality of the governance of a municipality has a direct impact on service delivery' (Dlalisa 2009:7, cited in Chaka 2013:1).

However, in recent years, municipalities have been confronted with civil protests because of service delivery backlogs (Jones \& Beattie 2011:59). For instance:

[T] he consolidated reports of the AGSA on the outcomes of the audit of local government for the last 9 years indicates [sic] that the majority of municipalities for the respective years were identified as not being financially sustainable. (AGSA 2011:11-89, 2012:12:90, 2013c:76, 2014:1, 2018:16, 2020:45; Chaka 2013:6; Dlamini, Mutambara \& Assensoh-Kodua 2017:46)

This raised concerns regarding the financial sustainability of the operations of the municipalities in question, as the provision of essential services and maintenance of infrastructure may be severely disrupted. Other factors that were found to have affected the abilities of these municipalities included the following (AGSA 2011:11-89, 2012:12:90, 2020:45): unusually high reliance on grants because one's own revenue is insufficient to fund operating costs, failure in terms of consumer debt recovery and current liabilities exceeding current assets. The situation is of great concern for the AGSA and the institution made specific recommendations, such as that the affected municipalities must put financial recovery plans in place to turn this situation around (Motubatse 2014:3). The AGSA further emphasised that the municipalities should act on their recommendations for strengthening their internal controls and the early warning signals they share with them as part of the status of records review (AGSA 2020:23-70).

Furthermore, many researchers have also highlighted that the audit challenges experienced by local governments globally are related to some of these factors: the quality of leadership, financial management and governance (AGSA 2012:11, 40; Dalton et al. 1998:270). These issues are also relevant to the challenges of implementing audit recommendations in the local government; in South Africa, this has been the target for all local governments across the country in that, by the end of the 2013/2014 financial period, all the municipalities must have achieved clean audit opinions (COGTA 2009:9). However, the target has been a challenge for all and unachievable in too many municipalities across the country. The AGSA and others have repeatedly reported weak leadership, poor financial management and the lack of effective governance as key obstacles to the achievement of clean audit opinions since the target was set in 2011 (AGSA 2013a:196, 2013b:87).

Gendron, Cooper and Townley (2007:110) underlined the essential nature of the auditor's expertise in issuing recommendations and constructing performance guidance measurements to improve the management of local government. Wilkins (1995:429) also pointed out that the improvement in public sector accountability can be achieved through audit results and recommendations. This means that public sector audits can be effective if auditors put audit recommendations into action for better government performance and resource management, which will improve the economy, efficiency and effectiveness in the local sphere of government (Gendron et al. 2007:110). Therefore, the implementation of the auditor general's (AG) recommendation is very essential, as it is a measure of the AGSA's effectiveness (AGSA 2016:12, 13). This means that if the AGSA's recommendations are considered and implemented yearly, there would be a reduction in adverse audit findings, which reflects positively on the AGSA.

However, the implementation of the AGSA's recommendations seems to be a major problem in the local South African municipalities. For example, in the report of the local government outcomes in 2013-2014, the chairperson of Parliament's Standing Committee on the Auditor General (SCAG), Mr Vincent Smith, stated that many of the recommendations of the AG were not being implemented (AGSA 2017:9). Smith further highlighted that (AGSA 2017):

[T] he AG makes recommendations and, year after year the same issues are repeated. Maybe we should look at it in the light of other chapter 9 institutions whose recommendations are strong so that it does not just become a recommendation that is dependent on [whether] an accounting officer or executive authority wants to implement it. (p. 9)

The problem of repeating findings previously reported supports the view that recommendations, guidelines and red-flagged risk areas are identified by the AGSA in all spheres of government, including the local government, but these recommendations are often either ignored or not effectively implemented (AGSA 2014:9,16, 2015:12). The AGSA also reports that there was adequate evidence that consequences did not often follow up on poor performance, gross negligence and fraudulent behaviour in all spheres of government, including the local government, in South Africa (AGSA 2012:5).

Moreover, the AGSA's report on national government also revealed that most of the public entities were not taking corrective action on the issues of irregularities raised in prior year audits; hence, some of the weaknesses remained unresolved or were recurring yearly (AGSA 2014:10, 2015:14, 2016:34).

Thus, the rationale for this study is to try to understand municipalities' audit inefficiencies, particularly why problems that recur in the AG's recommendations are not adequately resolved. The fact that over time problems come up again and again suggests that the root causes of these problems have probably not been addressed. This objective is achieved by reviewing various reports issued by the AGSA to determine whether (and why) simple problems continue to surface in spite of clear recommendations provided by the AG's recommendations to these municipalities. 


\section{Governance and audits in the public sector}

Auditing is an important element of the public organisation's management because of the public control that grows bigger and bigger as municipalities are getting more and more responsibility (Korje 2016:23). Government auditing is a cornerstone of good public sector governance (Fakie 1999:17). By providing unbiased, objective assessments of whether public resources are responsibly and effectively managed to achieve the intended results, auditors help government organisations achieve accountability and integrity, improve operations and instil confidence amongst citizens and stakeholders (Korje 2016:21). The government auditor's role supports the governance responsibilities of oversight, insight and foresight. Oversight addresses whether government entities are doing what they are supposed to do and serves to detect and deter public corruption. Insight assists decision-makers by providing an independent assessment of government programmes, policies, operations and results. Foresight identifies trends and emerging challenges. Auditors use tools such as financial audits, performance audits and investigation and advisory services to fulfil each of these roles (Korje 2016:24).

As an essential element of a robust public sector governance structure, auditing supports the governance roles of oversight, insight and foresight. Because the public sector's success is measured primarily by its ability to deliver services successfully and carry out programmes in an equitable and appropriate manner, public sector audit activities should have the authority and the competency to evaluate financial and programme compliance, effectiveness, economy and efficiency. Moreover, auditors also must protect the core values of the public sector, as it serves all citizens (Fakie 1999:19).

According to Motubatse, Ngwakwe and Sebola (2017:93), nearly all public sector organisations presently state that promoting good governance is a significant part of their strategic direction and agenda. Therefore, the relationship between governance and the implementation of successful audit recommendations in South African municipalities can be seen as a reflection of the municipalities' commitment to good governance. In the same view, good governance is accomplished when the public officials are held responsible for the use of the public resources entrusted to them and for the properly approved procurement and implementation of services such as healthcare, education and infrastructure, all of which are intended to benefit the citizens by creating stability and inspiring confidence in the way tax payers' money is being spent (Meyer 2015:13, cited in Motubatse et al. 2017:93).

Brinkerhoff and Brinkerhoff (2015) further argued that good governance at the local sphere of government is critical for developing countries, such a South Africa, to alleviate inefficiencies and impose fiscal discipline. The objectives of local government include the provision of services to communities in a sustainable manner, promotion of social and economic development within a safe and healthy environment, and encouragement of communities and community organisations to participate in local government matters (RSA 1996:82). Local government is thus the sphere of government responsible for delivering services to residents. In May 2016, the Mail \& Guardian (Steyn 2016:Online) reported that there were more service delivery protests in 2016 than in previous years.

Despite the dominant view that good governance enhances accountability, Grindle (2004:525) observed that governance structures and processes could be challenged when government and its employees perform poorly, that is, when resources are wasted and prescribed services are not provided regularly, if not at all. In addition, the absence of good governance invariably results in catastrophic audit outcomes (Deloitte 2014). According to the AGSA (2014), and the Presidency (2014), all South African municipalities face similar challenges. These challenges are deep-rooted and are the result of a generally poor understanding of governance and pieces of legislation related to administrative systems, an associated unwillingness to apply better processes of governance and, most importantly, being reluctant to implement audit recommendations provided by the AGSA (AGSA 2014; The Presidency 2014). Failure to implement the audit recommendation provided by the AG results in poor audit achievements on an annual basis. The study also found that some of the auditors within the municipalities lack a general understanding of government processes. Some are executing their functions without any proper training provided to them in order to better understand these processes (Khumalo 2007:72).

Another concerning issue encountered in the South African municipalities remains the repetition of negative findings previously reported by the AGSA, often on an annual basis. This issue is also noted by the AG, Mr T.K. Makwetu, during the discussions with the Parliamentary Portfolio Committee for Public Services and Administration (AGSA 2010:25), where he commented that it was not desirable for a 'Chapter 9 Institution to hark back to the same issues year after year'.

Ijeoma (2013:174) further emphasised on this concern that not only is the AGSA not empowered to demand accountability directly from executive authorities of public institutions and their subordinates, but also that there is recurring: irregular, fruitless and wasteful expenditure, and a conspicuous absence of consequences for poor performance or malfeasance particularly in the local sphere of government. This is evident in Limpopo local government as it topped the list of provinces with the highest percentage of 'unsatisfactory audit outcomes' at 82\% in the 2010-2011 financial year, which increased to $93 \%$ of poor audit outcomes in the 2011-2012 financial year (AGR 2011:56). In other words, the financial performance of the municipalities increasingly regressed rather than progressed (Ijeoma 2013:201). 
Negligence and weaknesses revealed by the audit each year raised the question about the extent of the municipality's implementation of audit recommendations (AGSA 2013b:13, 2014:19). In fact, the recurring audit issues result in a bad image of the South African government as a whole and the public wants a solution to be made immediately (Steyn 2016:Online). Implementation of the audit recommendations by the municipalities will result in enhanced accountability, improved operations, cost savings and the way of safeguarding of assets (Aikins 2012). This is because audit recommendations provide valuable methods in bridging the gap between the standards and actual practices at agencies as well as in providing learning information. The AGSA has determined that audit recommendations shall be included in a noncompliance report so that corrective actions can be taken, and the shortcomings are not being repeated (AGSA 2016).

Considering the above discussion, one can hold a view that municipalities in South Africa sometimes fail to take the recommendations provided by the AG into consideration. This is a concerning factor, as local government is at the centre of good public provision and it is often the first point of conduct between an individual or community and the central government or even the provincial government (AGSA 2010:56). In other words, power is decentralised to the municipalities to implement the national development agenda (Thornhill 2008:494) (Van des Nest, Thornhill, \& De Jager, 2008:547). It is therefore paramount that municipalities implement the audit recommendations in order to improve the use of public resources and deal with these highlighted challenges. Additionally, they need to implement the AGSA recommendations to improve management (accountability and transparency) so as to improve service delivery.

\section{Research methodology}

The research methodology used in this study was mainly qualitative and relied heavily on robust literature study (academic overview) and a review of key documents (specific reports on local government performance) in order to achieve the research objective. The researchers conducted the literature review in order to establish a theoretical framework that can be used to explain the lack of implementation of the AG's audit recommendations. The literature review thus identified the thematic root causes of non-implementation of audit recommendations within local government organisations. The AGSA is a Chapter 9 institution supporting South African democracy. The AGSA is required to perform mandatory audits of all government entities. Each year, the AGSA produces audit outcomes on government departments, public entities and municipalities (AGSA 2014). After the literature review, a review of key documents (the AGSA's annual audit reports) was conducted, information from AGSA reports was reviewed and key recurring findings were extrapolated.

The research population of this study includes all the municipalities in all the nine provinces of the Republic of South Africa. The studied population has been reported in the AGSA's local government audit outcome reports from
2009-2010 to 2018-2019. The number of local government entities in South Africa comprises 278 municipalities: 8 metros and 44 district municipalities and 226 local municipalities.

The reports that were considered from an AGSA perspective were those produced on audit outcomes for departments, public entities and municipalities for the financial years 2010-2011 up to and including, resulting in 11 reports (AGSA 2010, 2011, 2012, 2013a, 2013b, 2013c 2014, 2015, $2016,2017,2018,2019)$. For the purpose of this research, the researchers reviewed only official reports produced during the period covered by this research.

\section{Ethical consideration}

This article followed all ethical standards for a research without direct contact with human or animal subjects.

\section{Findings and discussion}

This study scrutinised the reports of the AGSA, which showed a distinction between matters reported for the first time and matters reported in both current and previous years. The analyses were conducted by identifying recurring themes grouped according to the drivers of internal control starting from the 2010 to 2019 financial year. Table 1 shows the statistics of the rate in which audit recommendations given by the AGSA are repeating in the South African municipalities.

The analysis of the findings in Table 1 shows that those who are charged with governance are not taking satisfactory measures to amend identified spillages and risks at the municipal level.

\begin{tabular}{|c|c|c|}
\hline Period & Audit recommendation type & $\begin{array}{l}\text { Number of audit } \\
\text { recommendations repeating } \\
\text { from the previous period }\end{array}$ \\
\hline \multirow[t]{3}{*}{ 2010-2011 } & Leadership & 5 \\
\hline & Financial and performance management & 5 \\
\hline & Governance & 3 \\
\hline \multirow[t]{3}{*}{ 2011-2012 } & Leadership & 4 \\
\hline & Financial and performance management & 8 \\
\hline & Governance & 1 \\
\hline \multirow[t]{3}{*}{ 2012-2013 } & Leadership & 4 \\
\hline & Financial and performance management & 5 \\
\hline & Governance & 2 \\
\hline \multirow[t]{3}{*}{$2013-2014$} & Leadership & 1 \\
\hline & Financial and performance management & 3 \\
\hline & Governance & 2 \\
\hline \multirow[t]{3}{*}{ 2014-2015 } & Leadership & 3 \\
\hline & Financial and performance management & 4 \\
\hline & Governance & 1 \\
\hline \multirow[t]{3}{*}{ 2015-2016 } & Leadership & 5 \\
\hline & Financial and performance management & 4 \\
\hline & Governance & 3 \\
\hline \multirow[t]{3}{*}{ 2016-2017 } & Leadership & 3 \\
\hline & Financial and performance management & 5 \\
\hline & Governance & 1 \\
\hline \multirow[t]{3}{*}{ 2018-2019 } & Leadership & 4 \\
\hline & Financial and performance management & 5 \\
\hline & Governance & 3 \\
\hline
\end{tabular}


Table 2 demonstrates the total figures of the rates in which audit recommendations given by the AGSA are repeated over the past 9-year period. These recommendations are grouped under the drivers of control and each shows a total percentage.

The analysis of the findings in Table 2 shows that the 'Financial and performance management' (including financial mismanagement, embezzlement, flouting the Public Finance Management Act (PFMA) and other Treasury directives, etc.) category has the most recurring recommendations with $47 \%$ within the 9-year period, suggesting that public funds are possibly not being managed in an effective and efficient manner in the respective municipalities. The second-most recurring recommendation category is 'Leadership' (including lack of leadership) with 35\%, suggesting that the leadership in the municipal level do not take audit recommendations given by the AGSA seriously. The last recommendation theme is 'Governance', which has the least amount of recurring recommendations compared with other groups, with $18 \%$. The consistent recurrence of themes and related findings implies that there are important factors influencing the successful implementation of audit recommendations in South African municipalities.

\section{The main causes of failure to implement the auditor general's recommendations in South African municipalities}

Literature analysis showed that failure to implement the recommendations of the AG can be caused by many factors, which include the availability of financial resources, human resources and time. According to Cohen and Savag (2010:297), 'the foundation of the implementation of audit implementation is the availability of resources and time to adopt the recommendations'. Abdullah (2014:6) further described, ' $[t]$ he unavailability of adequate funding results in the delay or nonimplementation of audit recommendations' It has to be emphasised that Abdullah's (2014:6) hypothesis presented here was deduced in an economic set-up other than South Africa. In fact, as this study will demonstrate in the following paragraph, the unavailability of financial resources and time

TABLE 2: Total number and percentage of audit recommendations recurring over a 9-year period.

\begin{tabular}{lcc}
\hline $\begin{array}{l}\text { Recommendation } \\
\text { category }\end{array}$ & $\begin{array}{c}\text { Total number of recommendations } \\
\text { over the 9-year period }\end{array}$ & $\begin{array}{c}\text { Overall percentage } \\
\text { for the 9-year period }\end{array}$ \\
\hline Leadership & 29 & 35 \\
$\begin{array}{l}\text { Financial and performance } \\
\text { management }\end{array}$ & 39 & 47 \\
\begin{tabular}{l} 
Governance \\
\hline
\end{tabular} & 16 & 18 \\
\hline
\end{tabular}

is not one of the three major factors that affected the implementation of audit recommendation in the South African municipalities during the period considered in this research. However, the notion of unavailability of resources in South Africa seems to be mainly around the issues of inadequate human resources capacity and lack of leadership. This notion also reflects on the extensive use of consultants in the municipalities when there are the personnel employed to do such work. This comes at a significant cost paid to consultants. To this end, consultancy costs for financial reporting services continued to increase over the past 10 years, amounting to R1.26 billion in 2019-2020 (AGSA 2020:21).

As the following paragraphs will show, these two factors also have influenced the implementation of audit recommendations given by the $A G$ in local government during the period covered by this research (AGSA 2016:46). Human capacity is a critical factor in the South African context. No government institution can achieve its objectives without the support of properly trained and committed human capital (PSC 2011:16). Inefficient utilisation of public resources is one of the many problems contributing to high levels of inefficiency in many South African municipalities and provincial governments (National Treasury 2015:3). As found from the AGSA reports, an inadequate resource can hamper the recruitment of additional personnel to ensure an adequate segregation of duties in the finance area (AGSA 2011:14). For example, the fact that municipalities take a very long time to fill vacant positions at senior management level with skilled and committed people contributes immensely to their failure to achieve their objectives. The vacant positions are reportedly filled on the basis of nepotism and political connections (cadre deployment) rather than fit for purpose (Deloitte 2012:3). In line with the issues of staffing, the AGSA report expressed serious concerns about the continued local governments' inabilities to manage vacancies especially 'in the key senior positions of municipal managers, chief financial officers and heads of supply chain management units' (AGSA 2013a:17, 2014:58, 2015:77-79) of the major problems facing the local government in South Africa, which have been compiled by Ramutsheli and Janse van Rensburg (2015:110), include the ones presented in Table 3.

From these results, it is clear that one of the reasons identified by many researchers, such as Ramutsheli and Janse van Rensburg (2015:110), Kanyane (2006:116), SALGA (2010) and Deloitte (2012:3), is that nepotism and cronyism continue to be the major contributing factor to the skills shortages in the South African local government. Nepotism and cronyism

TABLE 3: Vacant positions for senior managers.

\begin{tabular}{|c|c|c|c|c|}
\hline \multirow[t]{2}{*}{ Position } & \multicolumn{3}{|c|}{ Vacant positions as at year-end $(\%)$} & \multirow[t]{2}{*}{ Movement description } \\
\hline & 2011-2012 & $2012-2013$ & $2013-2014$ & \\
\hline Municipal Managers & 21 & 16 & 12 & $\begin{array}{l}\text { The rate decreased by } 5 \text { percentage points (or } 23.8 \% \text { ) in } 2012-2013 \text { and by further } 4 \text { percentage } \\
\text { points in 2013-2014. }\end{array}$ \\
\hline Chief Financial Officers & 23 & 27 & 13 & $\begin{array}{l}\text { The rate increased by } 4 \text { percentage points (or } 17.4 \% \text { ) in 2012-2013 but decreased by } 14 \\
\text { percentage points in 2013-2014. }\end{array}$ \\
\hline $\begin{array}{l}\text { Heads of Supply Chain } \\
\text { Management units }\end{array}$ & 21 & 31 & 24 & $\begin{array}{l}\text { The rate increased by } 10 \text { percentage points in } 2012-2013 \text { but decreased by } 7 \text { percentage points } \\
\text { in } 2013-2014 \text {. }\end{array}$ \\
\hline
\end{tabular}

Source: Ramutsheli, M.P. \& Janse van Rensburg, J.O., 2015, 'The root causes for local government's failure to achieve objectives', Southern African Journal of Accountability and Auditing Research 17(2), 110. 
remain the basis on which senior local government officials are appointed at the local government level. People who are appointed in these positions because of them being the cardcarrying members of the ruling parties are generally unqualified, lacking skills and inexperienced (Deloitte 2012:3; Kanyane 2006:116; SALGA 2010).

The second major factor found in the literature is the lack of vibrant audit committees in municipalities. According to Ibrahim, Baker and Doyle (2014:15), these are committees that are responsible for the following up of the implementation of audit recommendations of the ministries and government departments and bodies to determine the extent to which they have responded to the AG's recommendations. The audit committee can strengthen the organisation's ability to identify and assess risks. Van des Nest (2006:183) argued that '[a]udit committees are required to continuously review their oversight role in an effort to maintain their effectiveness'. The audit committee act stipulates that audit committees' performance needs to be evaluated on an annual basis and that such evaluation should include self-assessment and evaluation by management, internal and external auditors (Van des Nest 2006:183). Ibrahim et al. (2014:176) argued that the implementation of audit committee recommendations is one measure of the committee's usefulness and effectiveness. However, whilst literature suggests that a lack of vibrant audit committees hampers the implementation of the AG's recommendations, a review of the AGSA report shows that most governmental bodies (77\%) in South Africa that have been audited during the period covered by this research have established audit committees as prescribed by the legislation and recommended by the King Report III. More specifically, according to Sigidi (2012:14), 91\% of municipalities have established audit committees. However, despite the availability of the audit committees, it would seem that they were not performing their work properly. Van des Nest (2008:176) contended that although many audit committees exist in the South African public sector, the degree to which they are effective varies. Indeed, the present study found that a number of audit committees in the public sector are dysfunctional. One of the main reasons as to why audit committees are seemingly ineffective is that there is a shortage of people with financial auditing skills and technical expertise with respect to the internal control (Dodo 2017:19). The present study also identified other root causes leading to the audit committees' ineffectiveness, such as recruitment of committee members and political interference in the selection process, which need to be addressed.

The evaluation of audit committees' function needs to be done to determine whether it is discharging its role in line with its terms of reference in the charter (Deloitte 2011:48). Deloitte (2011:48) further argued that ' $f$ ] eedback from the evaluation is very important, as it can identify areas which need improvement by audit committees and ensures adequate alignment with the charter'. The charter refers to a formal document that defines audit committee's activities, purpose, authority and responsibility. Based on the discussion in this section, it is apparent that the complexities of the local government operations and an increasing need for effective leadership for the management of its resources require the local government to have an effective governance system in place to ensure that audit recommendations are effectively implemented (Deloitte 2011:5). Therefore, it is essential for audit committees in local government to demonstrate the 'worth' of following up audit recommendations whether they are implemented (Chaka 2013:83).

The fact that audit committees in many municipalities seem to be dysfunctional is a cause of concern, which needs urgent corrective actions. According to the National Treasury (20015:5), audit action-monitoring process is a remedial exercise to ensure that corrective action is taken on issues identified by the external auditors and internal auditors or the AGSA. Furthermore, monitoring progress is integral to the audit process in order to establish the status of agreed action plans or recommendations. Thus, reporting of the results of follow-up activities, in the form of a verbal or written report, is critical for senior executives and audit committees to have a better understanding of the status of internal controls, risk management and governance processes (National Treasury 2005:4). To monitor the implementation of audit findings and recommendations, the audit committee requires the internal audit to compile a formal findings register that would indicate corrective actions taken and list the unresolved findings. This could also assist the audit committee in overseeing how management is responding to the recommendations made by external and internal auditors. It may also assist the audit committee to affect accountability and to follow up on critical audit recommendations (Motubatse 2014:34). However, this present study found that some internal audit units have insufficient resources, which undermine their performance to function effectively. In other municipalities, the internal audit units are not afforded opportunities to attend training (Motubatse, Barac \& Odendaal 2015:16). A number of studies have also indicated that this could be simply the result of a lack of resources or planning foresight by the implicated municipalities (De Lange 2014:56; Enofe et al. 2013:162). Rubin (2011:78, cited in Wadesango, Chinamasa, Mhaka, \& Wadesango, 2017:51) also explained that the lack of audit action monitoring involves a process whereby auditors do not use effective communication channels, such as face-to-face approaches, in a clear, concise and organised manner to determine how findings and recommendations can best be presented to promote acceptance.

This is the case in the local government of South Africa. Presenting his audit report for the 2014-2015 financial year, the AG observed that management in $73 \%$ of auditees has been slow to respond to the recommendations aimed at assisting them to improve key controls and addressing risk areas. He further stated that '[i]f there is no follow up, municipalities will not be persuaded to do anything different' (AGSA 2015:23). In light of the above discussion, the study found that there are no formal audit action- 
monitoring processes in the South African municipalities, and this influences the managements' attitude for not committing themselves by responding swiftly to the AG's recommendations.

The third major problem causing failure to implement the AGSA recommendations is the AGSA's failure (or at least inability) to establish regular progress checks follow-up and monitoring to find out whether the recommendations given to the auditees by his or her office are being implemented. Recommendation monitoring is an ongoing responsibility and the status of open recommendations should be determined on a regularly scheduled basis. According to Aikins (2012:65), monitoring and follow-up systems can be sophisticated or rather simple depending on a number of factors, including the size and complexity of the audit client organisation. Zahran, Chulkov and Inomata (2010:54) stated that follow-up systems in place for implementing audit recommendations vary in terms of refinement and effectiveness as only a few organisations have implemented online systems. However, Daugherty et al. (2012:56) argued that it is the audit firm's or organisation's responsibility to be clear that audit follow-up is a significant and valued activity and that audit staff should not be made to believe that followup time must be borrowed from other activities considered more significant. Aikins (2012:45) stated that the follow-up activity performed by professionals is a process by which they determine the adequacy, effectiveness and timeliness of actions taken by the management on reported observations and recommendations, including those made by external auditors and others. According to Aikins (2012:45), a followup process should be established to help provide reasonable assurance that each review conducted by professionals provides optimal benefit to the enterprise by requiring that agreed-on outcomes arising from reviews are implemented in accordance with management undertakings or that management recognises and acknowledges the risk of delaying or not implementing proposed outcomes and/or recommendations.

Evidence suggests that the establishment of regular progress checks follow-up and monitoring to find out whether the recommendations are being implemented can yield positive results. For example, in South Africa, the Public Service Accountability Monitor (PSAM) was established as an independent research project at Rhodes University in 1999. It initially took on the task of tracking actions taken by the provincial administration in response to reported cases of corruption. A number of these cases had originally been identified in the AG's reports. Public Service Accountability Monitor collected this information in a database that was made available to the public on its website. The database shows that effective corrective action had been taken and there is information that citizens and civil society organisations could use to gauge the commitment of government agencies in combating corruption involving agency members (Khumalo 2007:43).
Over time, PSAM began to shift its focus to the structural context of weak financial management that was responsible for many of these acts of corruption and maladministration. It began to systematically monitor the compliance of provincial administrative agencies with public finance regulations and administrative directives. This included creating a database of information on the coherence of strategic planning within agencies and their annual and audit reports. In particular, PSAM monitored whether recommendations to improve financial controls made to agencies by the AG and the legislature's oversight committees were being implemented (Khumalo 2007:43).

Public Service Accountability Monitor utilises a wide range of means to obtain documents pertaining to financial management, maladministration and corruption including, when necessary, using freedom of information provisions. It publicises its findings on a regular basis by producing a weekly column (the 'Accountability Monitor') in a provincial newspaper. Public Service Accountability Monitor produces analysis that is geared towards public understanding and specifically designed to engender and support public involvement in governance processes. It endeavours to produce and distribute its analysis of public expenditure management in a manner timed to coincide with the budgeting and oversight cycle in order to influence budget and spending priorities and improve service delivery (Economic Governance and Management 2006:108). This present study is of the view that by establishing a regular progress checks follow-up and monitoring system, such as PSAM, municipalities will be able to encourage and force management to take into consideration the findings identified by the AGSA.

The fourth major problem identified in the above analysis is the lack of consequences for not implementing the AG's recommendations. Aikins (2012:59) argued that 'when status monitoring identifies dormant recommendations, follow ups should determine why action is not being taken'. He further argued that 'the environment could have changed such that the problem no longer exists or that the recommendation is no longer relevant or feasible' (Aikins 2012:60). In this instance, municipalities could be reluctant towards implementing AG's recommendations because there are no consequences for inactions from the respective municipalities. The AG, Mr T.K Makwetu, has also criticised the lack of consequences for senior officials responsible for unauthorised, fruitless, wasteful and irregular expenditure of state funds (AGSA 2012, 2013, 2014). In his financial report of 2013-2014, he stated that despite OAGSA's constant and insistent advice and caution to those charged with governance and oversight about administrative lapses since 2013, their counsel has largely not been heeded (AGSA 2015:14). The AG further reported that in 'the absence of consequences, the misuse of funds will continue unabated' (AGSA 2014:45). The AG is of the opinion that these matters are amongst the things that cause these audit outcomes to remain stuck or to continue to come out poor largely because of poor leadership, which has been highlighted oftentimes. 
The AG's statement on the continuing lack of consequences for those who do not implement audit recommendations in local government comes at a time when the parliamentary committee responsible for OAGSA, the SCOAG, 'is finalising its deliberations on possible amendments to the Public Audit Act, the legislation that governs the operations of the AGSA' (RSA 2016:13). The amendments will provide the OAGSA with the power to refer material irregularities to appropriate authorities to investigate as well as with a level of remedial power, including the recovery of money lost because of the irregularities (AGSA 2017:34). This study found that lack of power to impose sanctions on those who do not act on the findings identified by the AG is an indication that there will be no consequences that will take place; however, with the amendment of the Public Audit Act, the AGSA will be empowered to take actions against those who do not act on the $\mathrm{AG}^{\prime}$ 's recommendations.

Section 182 (1)(c) of the Constitution of South Africa empowers other Chapter 9 institutions, such as the Public Protector, to provide effective remedial actions for state misconduct on the basis of preliminary or prima facie findings. Such remedial actions have the force of law and their legal consequences must be complied with or acted upon (President of the Republic of South Africav The Office of the Public Protector and Others 2017). 'Compliance therewith is not optional and it has binding effect until properly set aside by a court of law' (Economic Freedom Fighters v Speaker, National Assembly and Others 2016).

However, neither the Constitution of the Republic of South Africa nor the High Court judgements empower Chapter 9 institutions such as the AGSA to enforce their own recommendations. However, as things stand now, Chapter 9 institutions depend on the good will of the other arms of the state, such as the executive or parliament, to enforce their decisions. The fact that Chapter 9 institutions are not empowered to enforce the implementation of their recommendations or remedial actions is one of the reasons why the AGSA recommendations have not been implemented. As a result, the National Assembly (NA) is of the view that amendments to the Public Audit Act of 2004 will empower the AG to recover monies lost through financial mismanagement and corruption and to refer fraud and irregularities to relevant agencies for investigation (RSA 2016:2). Mr Vincent Smith, chair of the SCAG, reiterated the importance of the bill, which he raised in the period when the AG released audit outcomes for local government. Smith stated that ' $[e]$ very cent of taxpayer money must be put to best use - for the benefit of citizens - not for a corrupted few in the public and private sector' (AGSA 2017:14).

Smith further emphasised the AG's frustration that since back from the year 2013 - 2017 the AG's constant and insistent advice had not been heeded by those charged with governance and oversight regardless of the fact that there is legislation in place, such as the PFMA and the Municipal Financial Management Act (MFMA); however, the situation with prudent financial management still left much to be desired (AGSA 2017:19). With this act, the AG will be able to make recommendations with remedial action that is binding much like the case with the Public Protector - to recover losses incurred. The AGSA is now of the view that continued mismanagement of taxpayers' money can be stopped and will be stopped when harsh consequence management is meted out (AGSA 2017:21). The AG will also be able to hold municipal officers to account for irregular expenditure. These may be the director generals of departments, as well as the management of boards, who are the primary custodians of public money. The AG can issue a debt certificate to accounting officers who are not compliant with the PFMA or the MFMA. The relevant director general, board or municipal manager will be personally liable to repay funds to the state for poor financial management (AGSA 2017:23).

Following the publication of the local government audit findings report of 2016-2017, the AG Mr Makwetu suggested that the bill would help to halt the deterioration in municipal finances. The AG's report showed that only 33 of the country's 278 municipalities received a clean audit in 2016-2017, compared with 48 the year before. Irregular expenditure rose to R28.4bn in the 2016-2017 financial year compared with $\mathrm{R} 16.2 \mathrm{bn}$ the previous year, an increase of $75 \%$. The AG's report also designates that of the 257 municipalities audited for the 2017-2018 financial year, of which only 18 received clean audits, showing a deterioration from the 33 municipalities that had received a clean audit in the previous year. In the latest local government audit findings report of 2018-2019 financial year, the AG's report has found that out of the 257 municipalities in the country, only 20 have been awarded clean audits. The AG further stated that repeated advice and warnings to accounting officers over the past 9 years had been ignored. Most municipalities are failing to act on the AG's findings and recommendations (AGSA 2017:27, 2018:31, 2020:33). Considering the above discussion, the present study is of the view that the new bill will influence most municipalities to consider AG's recommendation and act on them. This is because the new bill is now binding, and if municipal officers continue to ignore $\mathrm{AG}^{\prime}$ s findings and audit recommendations, the AG will take punitive actions against them.

The fifth and final major factor, which hampers the implementation of the AGSA recommendations, relates to the failure to track progress regarding implementation of audit recommendations. The factors pertaining to implementation of audit recommendations within the municipalities call for the establishment of monitoring and evaluation (M\&E) unit in the local government. At a municipal level, a part of M\&E functions includes, amongst others, municipalities reporting on their performance to the respective national and provincial government departments, legislature as well as other related local government stakeholders. This means that municipalities are supposed to produce credible quarterly, midyear and annual performance information reports that 
will be used for financial performance review and assessment by the above-mentioned stakeholders (National Treasury 2015:9). It is crucial for the institutions in charge of auditing (AGSA), monitoring and evaluation Department of Planning Monitoring and Evaluation(DPME) to communicate with each other for the benefit of municipals' financial performance. That communication should focus on covering their objectives, approaches and the tools they apply in order to get the most out of potential synergies. The M\&E unit should be seen as a complementary activity to strengthen the implementation of audit recommendations. This is because M\&E can provide robust and persuasive audit evidence to support the achievement of audit objectives in the local government (National Treasury 2015:13). Monitoring and evaluation unit is a strategy that South African municipalities may use to ascertain if existing recommendations given by the AGs are being implemented as they ought to be. Furthermore, M\&E provides critical information by which to determine the economy, efficiency and effectiveness of government action and the basis for holding accountable those that are responsible for implementing the policies and audit findings at the municipal level. The proper use of M\&E at the municipal level can save audit time and money (Presidency 2008:4). Through M\&E unit, the AGSA will be able to assess the performance of the municipality based on what was agreed upon in terms of plans or priorities (AGSA 2010:14). Consequently, this will lead to the achievement of the long-term results of the local government from the result-based M\&E (National Treasury 2015:16).

\section{Conclusion and recommendations}

This study was undertaken to identify factors that influence the effective implementation of audit recommendations given by the AG, with specific reference to South African municipalities. The AGSA's consolidated general reports on the audit outcomes of local government for the financial years of 2010-2011, 2011-2012, 2012-2013, 2013-2014, 2014-2015, 2015-2016, 2016-2017, 2017-2018 and 2018-2019 as well as other relevant literature were reviewed in order to achieve the objectives of this study.

The literature and data reviewed in this study identified factors that influence the successful implementation of audit recommendations in the South African municipalities. The study found that within the South African municipal setting, good governance plays an important role in ensuring the effective implementation of audit recommendation in the respective municipalities. The findings of this research show that the 'Financial and performance management' (including financial mismanagement, embezzlement, flouting the PFMA and other Treasury directives, etc.) category has the most recurring recommendations with a percentage of $47 \%$ within the 7-year period, suggesting that public funds have been consistently mismanaged effectively and efficiently in the respective municipalities. The findings also show a lack of 'Leadership' (including bad leadership) to be the second highest recurring factor hampering the implementation of the AGSA recommendations (with a percentage of 35\%) in the municipalities. The findings also show that a lack of or poor 'governance' (with a percentage of $18 \%$ of recurrences) has been the main recurring recommendation over many past years. The consistent recurrence of these themed recommendations implies that there are important factors influencing the successful implementation of audit recommendations in South African municipalities.

Amongst the many factors found to be hampering the implementation of the AGSA recommendations are the unavailability of financial resources and time. However, this was not one of the major factors that affected the implementation of audit recommendation in the South African municipalities during the period considered in this research. The problem of unavailability of resources in South Africa seems to be mainly around the issues of inadequate human resources capacity and lack of leadership. The research found that dealing with skills shortages is hampered by the fact that senior local government appointments seem to be based on whether the appointees support the political direction of the government or ruling party and not necessarily on their qualifications, skills and experience. The other major factor is the lack of vibrant audit committees in municipalities and the fact that where these committees are they do not do their job. In addition, the other factor is the AGSA's own failure (or at least inability) to establish regular progress checks follow-up and monitoring to find out whether the recommendations given to the auditees by his or her office are being implemented. This is exacerbated by the lack of consequences for failure to implement the AG's recommendations by the auditees because, until recently, the office of the AG did not have the power to enforce its own recommendations. There is a need for the NA to fast-track the amendments to the Public Audit Act of 2004 in order to empower the AG to recover monies lost through financial mismanagement and corruption and to refer fraud and irregularities to relevant agencies for investigation (RSA 2016). Finally, it is important to establish, capacitate and empower the M\&E unit to track progress in the implementation of audit recommendations. This study opens up further avenues of research to conduct a similar study in other spheres of government audited by the AGSA in order to get further input on the topic. As the study only focused on South African municipalities, other researchers can do further research on other spheres of government to find out what factors affect them in implementing the AG's recommendations.

\section{Acknowledgements}

This article is based on the Master of Arts dissertation completed at the University of Johannesburg by the first author (L.S.M.)under the supervision of the second author (D.E.U.), entitled 'Factors influencing the implementation of the auditor general's recommendations in South African municipalities'.

\section{Competing interests}

The authors have declared that no competing interests exist. 


\section{Authors' contributions}

Both authors contributed equally to this work.

\section{Funding information}

This research received no specific grant from any funding agency in the public, commercial or not-for-profit sectors.

\section{Data availability statement}

Data sharing is not applicable to this article as no new data were created or analysed in this study.

\section{Disclaimer}

The views and opinions expressed in this article are those of the authors and do not necessarily reflect the official policy or position of any affiliated agency of the authors.

\section{References}

Abdullah, K.O., 2014, 'The audit profession_ensuring quality service delivery', In Auditing Journal 1(1), 1-7.

Aikins, S.K., 2012, 'Determinants of Auditee adoption of audit recommendations: Local government Auditor's perspectives', Journal of Public Budgeting, Accounting \& Financial Management 24(2), 195-220. https://doi.org/10.1108/JPBAFM-2402-2012-B002

Apollo, M., 2008, 'Impact assessment of the local government reforms in Rwanda: The case study of Kigali City', Thesis - MPA, NMMU, Port Elizabeth.

Auditor General of South Africa (AGSA), 2010, Consolidated general report on the audit outcomes of local government 2008-09, Office of the Auditor-General South Africa, Pretoria.

Auditor General of South Africa (AGSA), 2011, Consolidated general report on the audit outcomes of local government 2009-10, Office of the Auditor-General South Africa, Pretoria.

Auditor General of South Africa (AGSA), 2012, Consolidated general report on the audit outcomes of local government 2010-11, Office of the Auditor-General South Africa, Pretoria.

Auditor General of South Africa (AGSA), 2013a, Consolidated general report on the audit outcomes of local government 2011-12, Office of the Auditor-General South Africa, Pretoria.

Auditor General of South Africa (AGSA), 2013b, Consolidated general report on the audit outcomes of local government 2011-12, Office of the Auditor-General South Africa, Pretoria.

Auditor General South Africa (AGSA), 2013c, Report of the Auditor-General of South Africa on a performance audit of the use of consultants at selected national departments, viewed 12 June 2018, from http://www.agsa.co.za/auditreports/ SAR.aspx.

Auditor General of South Africa (AGSA), 2014, Consolidated general report on the audit outcomes of local government 2012-13, Office of the Auditor-General South Africa, Pretoria.

Auditor General of South Africa (AGSA), 2015, Consolidated general report on the audit outcomes of local government 2013-14, Office of the Auditor-General South audit outcomes
Africa, Pretoria.

Auditor General of South Africa (AGSA), 2016, Consolidated general report on the audit outcomes of local government 2014-15, Office of the Auditor-General South Africa, Pretoria.

Auditor General of South Africa (AGSA), 2017, Consolidated general report on the audit outcomes of local government 2015-16, Office of the Auditor-General South Africa, Pretoria.

Auditor General of South Africa (AGSA), 2018, Consolidated general report on the audit outcomes of local government 2016-17, Office of the Auditor-General South Africa, Pretoria.

Auditor General of South Africa (AGSA), 2019, Consolidated general report on the audit outcomes of local government 2017-2018, Office of the Auditor-General audit outcomes of local
South Africa, Pretoria.

Auditor General Report (AGR), 2011, General report on the audit outcomes of the Limpopo, Office of the Auditor-General South Africa, Pretoria.

Auditor General Report, 2012, General report of the audit outcomes of the Limpopo local government: 2011-12, Office of the Auditor-General South Africa, Pretoria.

Auditor General of South Africa (AGSA), 2020, Consolidated general report on the audit outcomes of local government 2017-2018, Office of the Auditor-Genera South Africa, Pretoria.

Brinkerhoff, D.W. \& Brinkerhoff, J.M., 2015, 'Public sector management reform in developing countries: Perspectives beyond NPM orthodoxy', Public Administration and Development 35(4), 222-237. https://doi.org/10.1002/pad.1739
Chaka, M.M, 2013, 'An evaluation of the effectiveness of the audit Committee in the Westonaria Local Municipality' Master's in Public Administration Mini-Dissertation. North-West University, Potchefstroom.

Cohen, A. \& Sayag, G., 2010, 'Effectiveness of internal auditing, an empirical examination of its determinants in Israeli organisation', Australian Accounting Review 3(23), 296-307. https://doi.org/10.1111/j.1835-2561.2010.00092.x

Cooperative Governance and Traditional Affairs (COGTA), 2009, Local government turnaround strategy, Government Printers, Pretoria.

Dalton, D.R., Daily, C.M., Ellstrand, A.E. \& Johnson, J.L., 1998, 'Meta-analytic reviews of board composition, leadership structure, and financial performance', Strategic Management Journal 19(3), 269-290. https://doi.org/10.1002/(SICI)1097Management Journal 19(3), 269-290. https://doi.or
0266(199803)19:3\%3C269::AID-SMJ950\%3E3.0.CO;2-K

Daugherty, B.E., Dickins, D., Hatfield, R.C. \& Higgs, J.L., 2012, 'An examination of partner perceptions of partner rotation: Direct and indirect consequences to audit quality', Auditing: A Journal of Practice \& Theory 31(1), 97-114. https://doi. org/10.2308/ajpt-10193

De Lange, D., 2014, 'Management's responsibility to review internal financial controls', Official Journal of the Institute of Financial Officers 4(15), 14.

Deloitte, 2011, Audit committee- resource guide, viewed 17 February 2013, from http://www.corpgov.deloitte.com/site/us/audit-committee/audit-committee-res ourceguide/;jsessionid=ndyLTN2c9PygQJTFQ5FSXHv22mF1nWcNQ8d2vL1psm5h Sq3h93D7!1501908958! NONE.

Deloitte, 2012, Municipal clean audit efficiency series-Leadership ownership, viewed 13 June 2018, from http://deloitteblog.co.za.www102.cpt1.hosth.net/ wpcontent/uploads/2012/12/Municipal-Clean-Audit-Efficiency-SeriesLeadershipOwnership.pdf.

Dlamini, Z.V., Mutambara, E. \& Assensoh-Kodua, A., 2017, 'An investigation into the effectiveness of audit committees', Corporate Board: Role, duties and composition 13(2), 46-54. http://doi.org/10.22495/cbv13i2art5

Dlalisa, W.L., 2009, 'Strategies for enhancing good governance in South African local government', Master of Public Administration, University of Stellenbosch, Stellenbosch.

Dodo, A.A., 2017, 'Corporate collapse and the role of audit committees: A case study of Lehman Brothers', World Journal of Social Sciences 7(1), 19-29.

Economic Freedom Fighters v Speaker, National Assembly and Others 2016 (3) SA 580 (CC) paras [73]- (75].

Economic Governance and Management, 2006, The South African Institute of International Affairs (SAIIA), Government Printing Works, Pretoria.

Enofe, A.O., Mgbame, C.J., Osa-Erhabor, V.E. \& Ehiorobo, A.J., 2013, 'The role of internal audit in effective management in public sector', Research Journal of Finance and Accounting 4(6), 162-168.

Fakie, S., 1999, 'The role of the office of the auditor-general in South Africa', Unpublished Masters Dissertation, Durban.

Gendron, Y., Cooper, D.J. \& Townley, B., 2007, 'The construction of auditing expertise in measuring government performance', Accounting, Organisations and Society 32(1/2), 101-129. https://doi.org/10.1016/j.aos.2006.03.005

Grindle, M.S., 2004, 'Good enough governance: Poverty reduction and reform in developing countries', Governance: An International Journal of Policy Administration and Institution 17(4), 525-548. https://doi.org/10.1111/j.0952Administration and

Ibrahim, M.O, Baker, T. \& Doyle, S., 2014, 'Grappling with Section 404, Internal Auditor', Institute of Internal Auditors Journal 5(2), 57-61.

Ijeoma, E., 2013, South Africa's public administration in context, 1st edn., Verity Publishers, Pretoria.

Jones, G. \& Beattie, C., 2015, 'Local government internal audit compliance', Australasian Accounting, Business and Finance Journal 9(3), 59-71. https://doi. org/10.14453/aabfj.v9i3.5

Kanyane, M.H., 2006, 'Municipal skills challenges for accelerated service delivery in South Africa', Journal of Public Administration 41(3), 112-118.

Khumalo, M., 2007, 'An investigation of the efficacy of the Office of the Audito General in ensuring public financial accountability in the Gauteng Province', Unpublished Masters Mini-thesis, University of Fort Hare, Alice.

Korje, B.G., 2016, 'Assessment of implementation of audit recommendations in public sectors in Oromia Regional Government Public Institutions (2003-2006 E.C.)', The International Journal of Business \& Management 4(2), 21-32.

Matlala, L.S., 2018, 'Factors influencing the implementation of the auditor-general's recommendations in South African municipalities', MA Dissertation, University of Johannesburg

Meyer, I., 2015, Western Cape Government achieves $100 \%$ in audit outcomes, viewed 24 March 208, from https://www.westerncape.gov.za/news/wcg-achieves-100audit-outcomes.

Motubatse, K.N., 2016, 'An evaluation of factors affecting the progression to clean audit outcomes in South African municipalities', Unpublished research thesis in fulfilment for the degree of Doctor in Public Administration, University of Limpopo.

Motubatse, K.N., Barac, K. \& Odendaal, E., 2015, 'Perceived challenges faced by the internal audit function in the South African public sector: A case study of The National Treasury', African Journal of Science, Technology, Innovation The National Treasury', African Journal of Science, Technology, Innovation
and Development 7(6), 401-407. https://doi.org/10.1080/20421338.2015. 1096510 
Motubatse, K.N., Ngwakwe, C.C. \& Sebola, M.P., 2017, 'The effect of governance on clean audits in South African municipalities', African Journal of Public Affairs 9(5), 90-102.

National Treasury, 2015, The state of local government finances and financial management, Government Printing Works, Pretoria.

Presidency, 2008, The role of premiers' Offices in government wide monitoring and evaluation: A good practice guide, Presidency, Pretoria.

Presidency, 2014, The medium term strategic framework: 2014-2019, viewed 03 October 2015, from http://www.thepresidency-dpme.gov.za/keyfocusareas/ outcomesSite/Pages/the-Outcomes-Delivery-Agreements.aspx.

President of the Republic of South Africa v The Office of the Public Protector and Others 2017/91139/2016.

Public Service Commission South Africa (PSC), 2011, Fact sheet on the state of the public service, viewed n.d., from http://www.psc.gov.za/documents/2013/ FACT\%20SHEET\%20ON\%20THE\%20STATE\%20OF\%20THE\%2OPUBLIC\%20 SERVICE\%20-\%2OFINAL(2).pdf

Ramutsheli, M.P. \& Janse van Rensburg, J.O., 2015, 'The root causes for local government's failure to achieve objectives', Southern African Journal of Accountability and Auditing Research 17(2), 107-118.

Republic of South Africa (RSA), 1996, Constitution of the Republic of South Africa (Constitution), No. 108 of 1996, Government Printing Works, Pretoria.

Republic of South Africa (RSA), 2016, Public Audit Act 24 of 2014. Government Gazette, 27121:474, Government Printer, Pretoria.

Sigidi, M., 2012, 'Operation clean audit for 2014', Paper presented at the AuditorGeneral of South Africa's records management seminar, Kempton Park, 20th April.
South African Local Government Association (SALGA), 2010, 'Local government leading the fight against corruption', Paper Presented at the SALGA National Conference, South Africa, 29th August to 01st September 2011, viewed 22 June 2018, from South Africa, 29th August to 01st September 2011, viewed 22 June 2018, from
http://salga.org.za/app/webroot/assets/files/Presentations/Local\%20 http://salga.org.za/app/webroot/assets/files/Presentations/Loca

Steyn, L., 2016, 'Service delivery protests set for new highs this election year', Mail \& Guardian, 18 May 2016, viewed 18 September 2016, from http://mg.co.za/ article/2016-05-18-service-delivery-protests-set-for-new-highs.

Thornhill, C., 2008, 'The transformed local government system: Some lessons', Journa of Public Administration 43(3), 492-511.

Van des Nest, D.P., 2006, 'The perceived effectiveness of audit committees in the South African public sector', Meditari Accountancy Research 16(2), 175-188.

Van des Nest, D.P., Thornhill, C. \& De Jager, J., 2008, 'Audit committees and accountability in the South African public sector', Journal of Public Administration 43(4), 545-558. https://doi.org/10.1108/10222529200800019

Wadesango, N., Chinamasa, T., Mhaka, C., \&Wadesango V.O., 2017, 'Challenges faced by management in implementing audit recommendations: A literature review' Risk Governance and Control: Financial Markets \& Institutions 7(4), 51-61. http:// doi.org/10.22495/rgc7i4art6

Wilkins, P., 1995. 'Performing auditors?: assessing and reporting the performance of national audit offices-a three country comparison', Australian Journal of Public Administration 54(4):421-430. https://doi.org/10.1111/j.1467-8500.1995. tb01154.x

Zahran, M., Chulkov, V. \& Inomata, T., 2010, The audit function in the United Nations system, Joint Inspection Unit Geneva. 